\title{
PENERAPAN ALGORITMA ARI BORNEO (AB) UNTUK PEMBACAAN TEKS DENGAN MEMANFAATKAN MICROSOFT SPEECH DAN ID1
}

\author{
Ari Restani, Anton Setiawan Honggowibowo, Yuliani Indrianingsih \\ Teknik Informatika STTA Yogyakarta \\ Informatika@stta.ac.id
}

\begin{abstract}
Reading is an activity person to obtain information from something written. Reading involves recognition of the symbol and the letters that make a language. But there are some people who are lazy to read text in English language which is not a language that is used everyday by Indonesian people. In addition to reading, there are also the most common activities to obtain information that is heard. Hear is a way to gain an understanding of the meaning of the information in the form or sound using auditory senses. Reading activities contributed 10\% ability for know information, with listening, knowing information can reach $30 \%$. With conditions like this, then it needs an alternative media that can help treat the condition. The alternative media that can be made is text to speech for read text in Indonesia language and English language, for detection language using Ari Borneo Algorithm. These systems are made using Delphi 7 programming language, MBROLA Tools as Indonesia-speaking sound generators and Microsoft Speech API as English sound generator. Through this system, users can absorb information from listening to the reading of text by both systems.
\end{abstract}

Keywords : reading, listening, Text to Speech, translator, AB Algorithm.

\section{PENDAHULUAN}

Membaca adalah suatu kegiatan yang dilakukan seseorang untuk mendapatkan

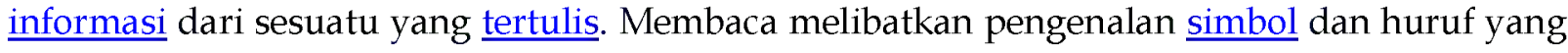
menyusun sebuah bahasa. Selain membaca, ada juga kegiatan yang paling umum untuk mendapatkan informasi yaitu mendengar. Mendengar adalah suatu cara untuk memperoleh pengertian atau arti dari informasi berupa suara menggunakan indra pendengaran. Dengan demikian mendengar bukan hanya sekedar mendengarkan bunyi-bunyi bahasa melainkan juga memahami artinya.

Kegiatan membaca memberikan andil penguasaan materi $10 \%$, sedangkan dengan mendengar, penguasaan materi bisa mencapai 30\%. Mendengarkan berkaitan dengan penggunaan bahasa ragam lisan, sedangkan membaca merupakan aktivitas berbahasa ragam tulis. Perbedaannya hanya pada objek yang menjadi fokus perhatian awal. Pada saat mendengarkan fokus perhatian berupa suara, sedangkan pada membaca adalah tulisan.

Tetapi ada sebagian orang yang malas untuk membaca apalagi teks tersebut merupakan bahasa Inggris yang bukan merupakan bahasa yang digunakan sehari-hari oleh orang Indonesia.

Melihat kondisi seperti ini, maka dibutuhkan adanya suatu media alternatif yang dapat dibuat untuk membantu mengatasi kondisi tersebut. Salah satu media alternatif yang dapat dibuat, yaitu sistem pembaca teks bahasa Indonesia dan bahasa Inggris, dimana bahasa yang 
digunakan untuk membacakan teks dideteksi menggunakan Algoritma Ari Borneo (AB). Dengan pemanfaatan teknologi informasi, proses pendeteksian bahasa pada teks dan pembacaan teks dilakukan oleh komputer menggunakan suatu sistem yang merupakan salah satu aplikasi dalam bidang teknologi bahasa dan juga kecerdasan buatan. Sehingga pada penelitian Tugas Akhir ini akan dibuat suatu algoritma yang dalam penerapannya dapat mendeteksi bahasa pada teks, dalam hal ini bahasa yang digunakan adalah bahasa Indonesia dan bahasa Inggris, kemudian teks tersebut akan dikonversi menjadi ucapan sesuai dengan teks bahasa yang sudah dideteksi yakni bahasa Indonesia dan bahasa Inggris.

\section{LANDASAN TEORI}

\section{a. Tinjauan Pustaka}

Iwan Iwut Tritoasmoro dari Sekolah Tinggi Teknologi Telkom Bandung tahun 2006 dalam jurnal dengan judul Text-To-Speech Bahasa Indonesia Menggunakan Concatenation Synthesizer Berbasis Fonem membahas tentang perancangan sistem Text To Speech Bahasa Indonesia yang mampu menghasilkan sinyal ucapan yang jelas dan alami dengan synthesizer perangkaian berbasis fonem, sehingga diharapkan diperoleh sistem Text To Speech dengan kompleksitas yang lebih rendah dan lebih hemat memori.

Agustinus Noertjahyana dan Rudy Adipranata dalam jurnal dengan judul Implementasi Sistem Pengenalan Suara Menggunakan Sapi 5.1 Dan Delphi 5 membahas tentang perancangan sistem Text To Speech menggunakan Microsoft Speech API 5.1.

\section{b. Teknologi Pemrosesan Bahasa Alami}

Pada prinsipnya bahasa alami adalah suatu bentuk representasi dari suatu pesan yang ingin dikomunikasikan antar manusia. Bentuk utama representasinya adalah berupa suara/ucapan (spoken language), tetapi sering pula dinyatakan dalam bentuk tulisan. (Arry Akhmad Arman, 2008).

\section{c. Algoritma Ari Borneo}

Pada tugas akhir ini, dibuat sebuah algoritma baru yaitu Algoritma AB yang dibuat Ari Restani. Ide dasar pembuatan algoritma ini adalah untuk pengecekan bahasa yang terdapat pada sebuah paragraf. Setiap kata akan dicocokkan dengan library yang ada. Library bahasa yang memiliki jumlah kecocokkan yang lebih banyak, maka teks pada paragraf tersebut akan dibacakan menggunakan bahasa yang cocok.

\section{PERANCANGAN ALGORITMA}

Alur Algoritma AB dalam proses pengecekan bahasa dalam sebuah paragraf adalah sebagai berikut :

1. Kalimat yang terdapat dalam paragraf dipecah menjadi kata.

2. Setiap kata yang sudah dipecah akan dibandingkan dengan library bahasa Indonesia dan bahasa Inggris.

3. Setiap kecocokan antara kata dan library diberikan nilai 1, jika tidak ada kecocokan akan diberikan nilai 0 .

4. Bila jumlah kecocokan kata dalam satu paragraf dengan library bahasa Indonesia lebih banyak daripada library bahasa Inggris, maka bahasa yang digunakan untuk pembacaan teks adalah bahasa Indonesia. 
5. Bila jumlah kecocokan kata dalam satu paragraf dengan library bahasa Inggris lebih banyak daripada library bahasa Indonesia, maka bahasa yang digunakan untuk pembacaan teks adalah bahasa Inggris.

\section{IMPLEMENTASI}

\section{a. Konfigurasi MBROLA Tools}

Sebelum menjalankan aplikasi ini harus dilakukan konfigurasi terlebih dahulu pada MBROLA Tools untuk menentukan default diphone database yang akan digunakan dalam aplikasi ini. Tampilan MBROLA Tools control panel dapat dilihat pada gambar 1.

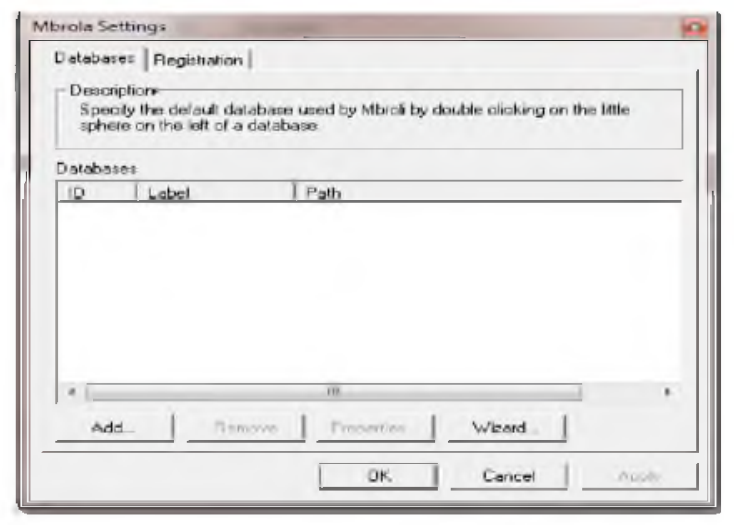

Gambar 1 Tampilan MBROLA Tools control panel

Setelah berada pada MBROLA Tools control panel, selanjutnya adalah proses konfigurasi diphone database yang akan digunakan untuk aplikasi ini, proses yang dillakukan adalah dengan meng-klik button add untuk menambahkan diphone database yang digunakan untuk menjalankan aplikasi, tampilan untuk proses konfigurasi diphone database dapat dilihat seperti pada gambar 2 .

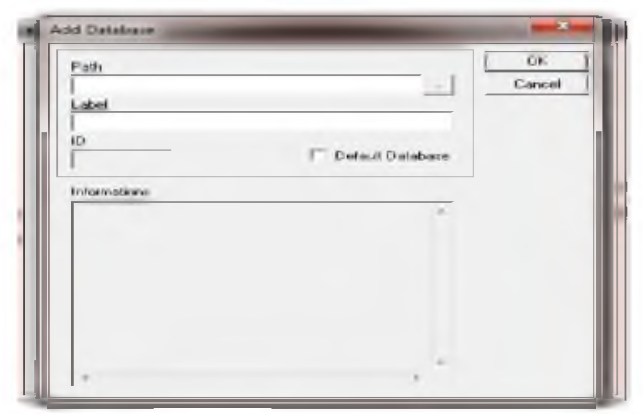

\section{Gambar 2 Tampilan Add Database MBROLA Tools}

Setelah ke tampilan add database, proses selanjutnya yang dilakukan adalah dengan menklik button load file di button Path untuk proses pencarian diphone database, kemudian akan muncul tampilan kotak dialog open database untuk menemukan diphone database yang akan digunakan sebagai default database, pilih diphone database yang digunakan yaitu dengan kode id1, proses pemilihan diphone database dapat dilihat pada gambar 3 . 


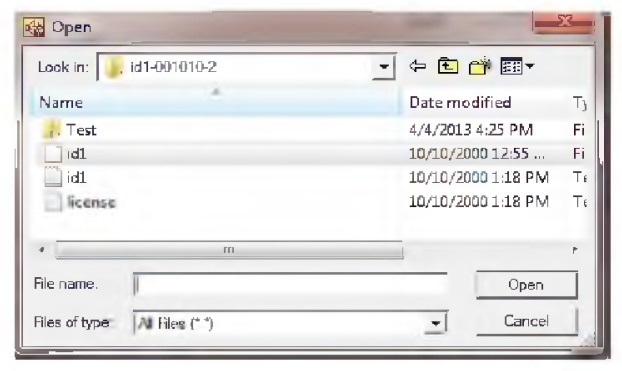

Gambar 3 Tampilan Open Database MBROLA Tools

Setelah default database yang akan digunakan dalam aplikasi sudah ditentukan, maka path database akan berisi informasi lokasi diphone database tersebut disimpan, label database akan berisikan nama diphone database yaitu id1, kemudian kolom informasi juga berisi informasi mengenai diphone database yang digunakan, tampilan dapat dilihat pada gambar 4 .

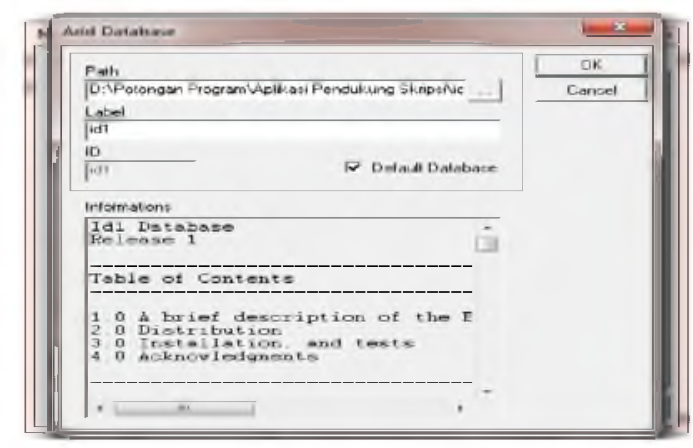

Gambar 4 Tampilan Add Database MBROLA Tools

Kemudian setelah itu untuk menyelesaikan proses konfigurasi, klik button OK, maka tampilan akan kembali ke MBROLA Tools control panel, dan informasi database sudah ada di kolom databases pada tampilan MBROLA Tools control panel, tampilan MBROLA Tools control panel yang sudah terkonfigurasi dapat dilihat pada gambar 5

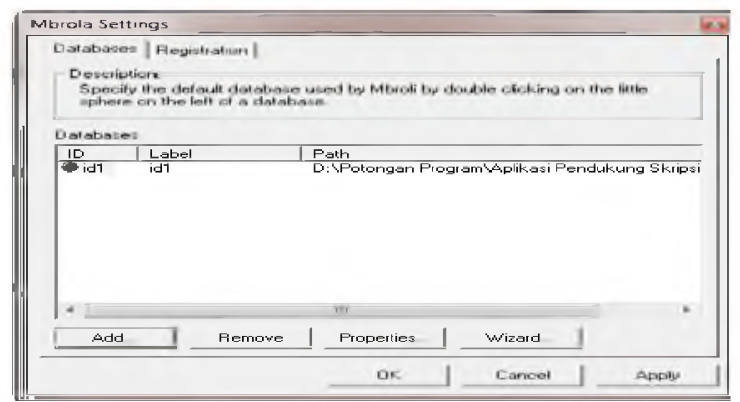

Gambar 5 Tampilan MBROLA Tools control panel

Setelah kembali ke tampilan MBROLA Tools control panel, klik button apply dan button OK, proses konfigurasi diphone database pada MBROLA Tools selesai.

\section{b. Tampilan Awal Aplikasi}

Tampilan utama yang ditampilkan aplikasi konversi teks ke ucapan dengan penerjemah bahasa ini memiliki 2 pilihan menu dengan 2 submenu, 1 memo, dan 2 button, tampilan awal aplikasi dapat dilihat pada gambar 6 . 


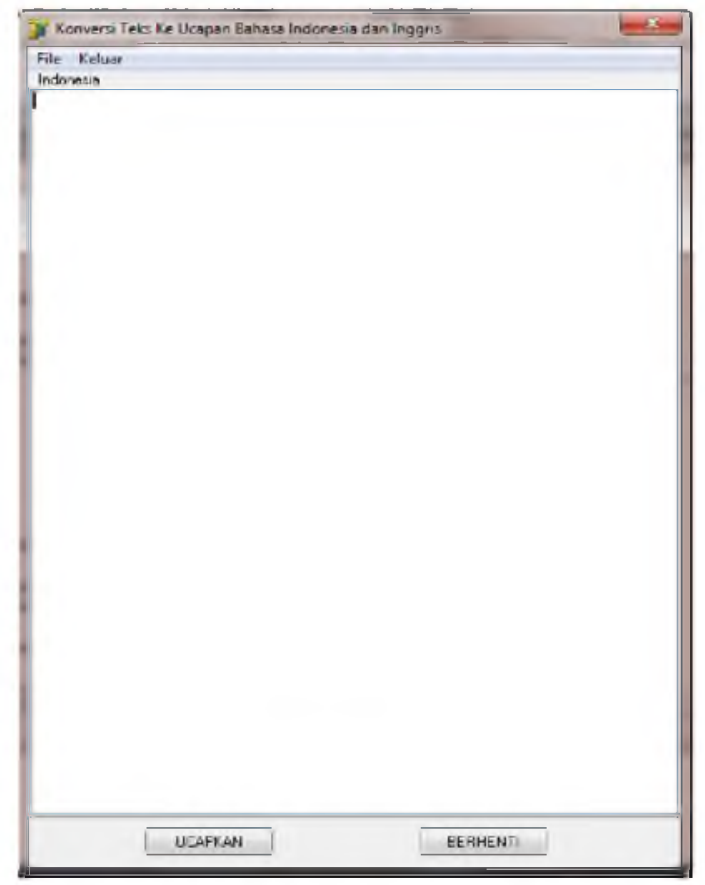

Gambar 6 Tampilan Awal Aplikasi Konversi Kata Ke Ucapan

Adapun fungsi dari masing-masing 2 pilihan menu dengan 2 submenu, 1 memo dan 2 button pada aplikasi ini adalah sebagai berikut:

1. Menu file, terdiri dari sub menu file baru yang berfungsi untuk menghapus tulisan yang terdapat pada memo, dan terdapat buka file yang berfungsi untuk mencari file baru yang akan dibacakan oleh aplikasi.

2. Menu keluar berfungsi untuk keluar dari aplikasi.

3. Memo, berfungsi untuk memuat teks yang akan dibacakan oleh aplikasi.

4. Button UCAPKAN, berfungsi untuk memulai pembacaan teks sesuai bahasa yang sudah terdeteksi oleh sistem yaitu bahasa Indonesia dan bahasa Inggris.

5. Button BERHENTI, berfungsi untuk menghentikan pembacaan kata atau kalimat, baik yang belum diterjemahkan maupun yang belum diterjemahkan.

\section{b. Proses Input Teks}

Proses input teks dilakukan untuk memasukkan teks berbahasa Indonesia atau berbahasa Inggris yang akan dibacakan ke dalam memo, teks berupa file dokumen dengan ekstensi *.txt dan *.doc, teks dokumen bisa dicari dengan mengklik submenu file baru atau bisa juga langsung diketikan manual dengan keyboard ke dalam memo source dan memo result. Proses dapat dilihat pada gambar 7 . 


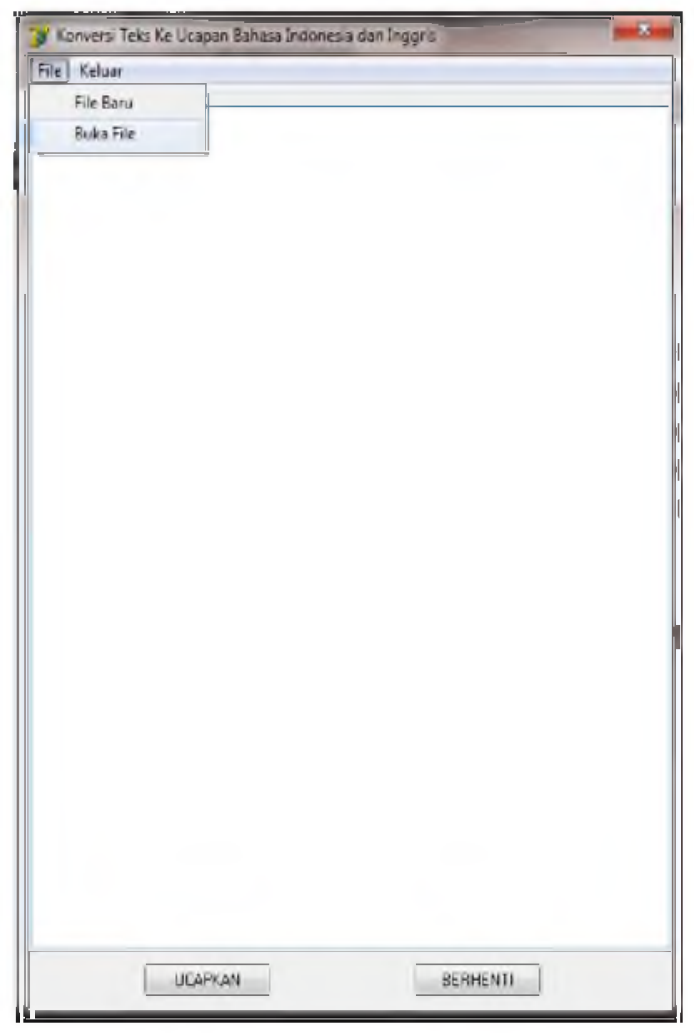

Gambar 7 Tampilan Proses Input Teks

\section{c. Proses Pembacaan Teks}

Proses pembacaan teks dilakukan untuk membacakan teks. Klik button UCAPKAN untuk membacakan teks, maka teks yang terdapat pada memo akan dibacakan, klik button BERHENTI jika ingin pembacaan berhenti. Proses pembacaan teks dapat dilihat pada gambar 4.8 .

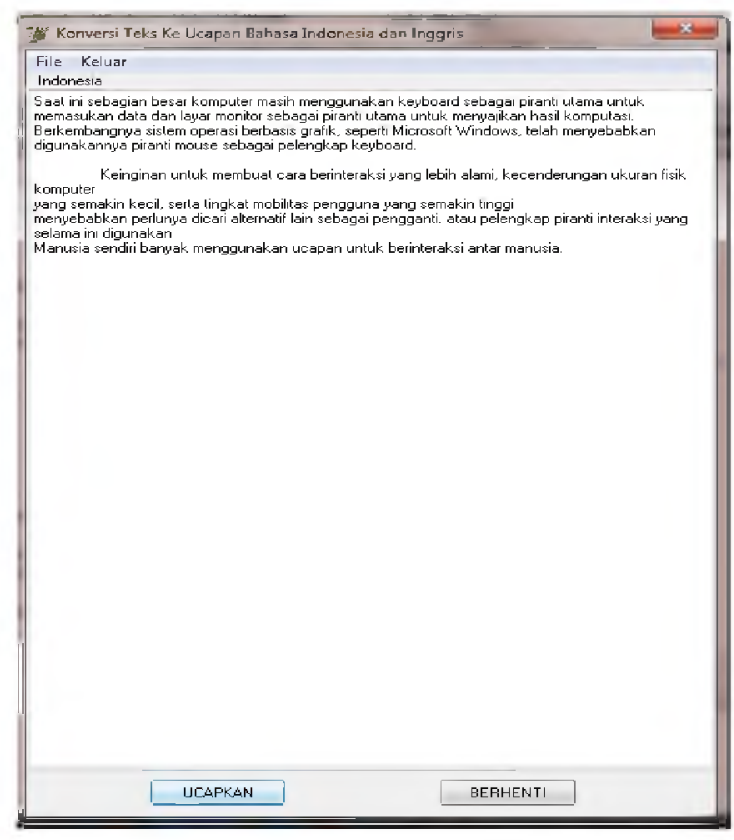

Gambar 8 Tampilan Proses Pembacaan Teks 
Jika ingin keluar dari aplikasi maka klik menu exit. Informasi yang ditampilkan dapat dilihat pada gambar 9 .

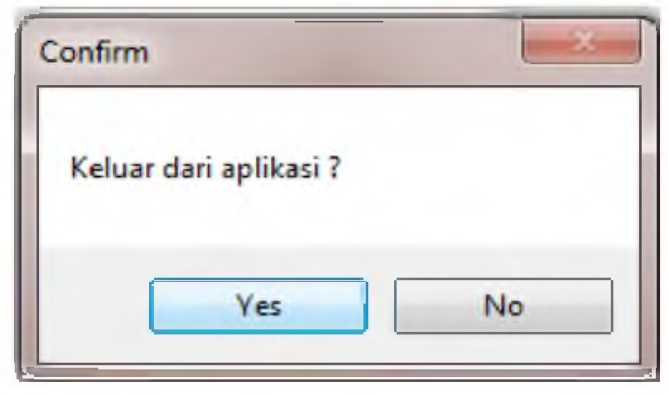

Gambar 9 Tampilan menu keluar

\section{d. Uji Coba Fungsi}

Uji fungsi ini dimaksudkan untuk melakukan pengujian terhadap sistem yang dibangun apakah sudah berjalan dengan baik atau belum. Proses aplikasi yang diuji adalah proses pembacaan teks, dalam proses ini akan dimasukkan 7 paragraf dengan dua bahasa yang berbeda yaitu bahasa Indonesia dan bahasa Inggris. Tujuan pengujian ini adalah untuk mengetahui apakah aplikasi dapat berjalan dengan baik jika pola urutan paragraf berubah, hasil pengujian dapat dilihat pada tabel 1.

Tabel 1 Hasil Pengujian Pembacaan Teks

\begin{tabular}{|l|c|}
\hline \multicolumn{1}{|c|}{ Format Paragraf } & Hasil Pengujian \\
\hline 7 Paragraf berbahasa Indonesia & Berhasil \\
\hline 7 Paragraf berbahasa Inggris & Berhasil \\
\hline $\begin{array}{l}\text { 1 Paragraf berbahasa Indonesia, 6 paragraf berbahasa } \\
\text { Inggris }\end{array}$ & Berhasil \\
\hline $\begin{array}{l}\text { 2 Paragraf berbahasa Indonesia, 5 paragraf berbahasa } \\
\text { Inggris }\end{array}$ & Gagal \\
\hline $\begin{array}{l}\text { 3 Paragraf berbahasa Indonesia, 4 paragraf berbahasa } \\
\text { Inggris }\end{array}$ & Gagal \\
\hline $\begin{array}{l}\text { 4 Paragraf berbahasa Indonesia, 3 paragraf berbahasa } \\
\text { Inggris }\end{array}$ & Gagal \\
\hline $\begin{array}{l}\text { 5 Paragraf berbahasa Indonesia, 2 paragraf berbahasa } \\
\text { Inggris }\end{array}$ & Gagal \\
\hline $\begin{array}{l}\text { 6 Paragraf berbahasa Indonesia, 1 paragraf berbahasa } \\
\text { Inggris }\end{array}$ & Gagal \\
\hline
\end{tabular}

Penjelasan dari tabel hasil pengujian proses pembacaan teks diatas adalah sebagai berikut:

a. Pembacaan teks dapat diasumsikan berhasil apabila seluruh paragraf dapat dibacakan oleh sistem.

b. Pembacaan teks dapat diasumsikan gagal apabila sistem tidak dapat membacakan seluruh paragraph atau hanya sebagian paragraf saja. 
c. Pembacaan teks dengan format 7 paragraf berbahasa Indonesia dikatakan berhasil karena semua paragraf yang dimasukkan dapat dibacakan oleh sistem.

d. Pembacaan teks dengan format 7 paragraf berbahasa Inggris dikatakan berhasil karena semua paragraf yang dimasukkan dapat dibacakan oleh sistem.

e. Pembacaan teks dengan format 1 paragraf berbahasa Indonesia dan 6 paragraf berbahasa Inggris dikatakan berhasil karena semua paragraf yang dimasukkan dapat dibacakan oleh sistem.

f. Pembacaan teks dengan format 2 paragraf berbahasa Indonesia dan 5 paragraf berbahasa Inggris dikatakan gagal karena sistem hanya dapat membacakan 2 paragraf pertama, sedangkan 5 paragraf selanjutnya tidak dapat dibacakan.

g. Pembacaan teks dengan format 3 paragraf berbahasa Indonesia dan 4 paragraf berbahasa Inggris dikatakan gagal karena sistem hanya dapat membacakan 3 paragraf pertama, sedangkan 4 paragraf selanjutnya tidak dapat dibacakan.

h. Pembacaan teks dengan format 4 paragraf berbahasa Indonesia dan 3 paragraf berbahasa Inggris dikatakan gagal karena sistem hanya dapat membacakan 4 paragraf pertama, sedangkan 3 paragraf selanjutnya tidak dapat dibacakan.

i. Pembacaan teks dengan format 5 paragraf berbahasa Indonesia dan 2 paragraf berbahasa Inggris dikatakan gagal karena sistem hanya dapat membacakan 5 paragraf pertama, sedangkan 2 paragraf selanjutnya tidak dapat dibacakan.

j. Pembacaan teks dengan format 6 paragraf berbahasa Indonesia dan 1 paragraf berbahasa Inggris dikatakan gagal karena sistem hanya dapat membacakan 6 paragraf pertama, sedangkan 1 paragraf selanjutnya tidak dapat dibacakan.

\section{e. Analisa Hasil Uji Coba}

Hasil dari semua percobaan dapat dianalisa dari simulasi percobaan proses mekanisme kerja dari sistem secara keseluruhan. Hasil analisa terdiri dari konsep dasar yang dibangun untuk menjadi sebuah sistem dengan apa yang telah dibahas pada bab sebelumnya. Analisa dari hasil percobaan adalah sebagai berikut :

a. Input teks dapat dilakukan dengan dua cara yaitu secara manual menggunakan keyboard maupun dengan file yang sudah ada dalam komputer pengguna sehingga lebih fleksibel.

b. Jika terdapat dua bahasa dalam satu teks yang dimasukkan ke dalam memo, maka aplikasi dapat mendeteksi bahasa pada teks, yaitu bahasa Indonesia dan bahasa Inggris.

c. Microsoft Speech API sebagai pembangkit suara berbahasa Inggris menghasilkan suara dan intonasi yang cukup jelas untuk didengar oleh pengguna, suara yang dihasilkan adalah suara perempuan.

d. MBROLA Tools sebagai pembangkit suara berbahasa Indonesia dengan metode diphone concatenation juga memberikan suara dan intonasi yang jelas untuk pengguna, suara yang dihasilkan adalah suara laki-laki.

e. Suara yang dihasilkan cukup jelas untuk di dengar sehingga pengguna dapat menyerap informasi yang ada pada teks dengan mendengarkan pembacaan yang dilakukan oleh sistem.

\section{f. Analisa Source Code Microsoft Speech API}

Analisa source code dibawah ini adalah analisa source code untuk Microsoft Speech API, analisanya adalah sebagai berikut :

1. NgomongInggris(MResult.Text); Baris program ini digunakan untuk memanggil prosedur pengucapan teks berbahasa Inggris. NgomongInggris adalah prosedur untuk pengucapan 
teks berbahasa Inggris, (MResult.Text) merupakan parameter yang berisi teks yang akan dibacakan oleh sistem.

2. oVoice:=CreateOLEObject('SAPI.SpVoice'); oVoice.Speak(Text, SVSFlagsAsync); Baris program CreateOLEObject('SAPI.SpVoice'); berfungsi untuk membuat objek Speech API, sedangkan oVoice.Speak(Text) berfungsi untuk membacakan teks berbahasa Inggris.

3. Repeat Application.ProcessMessages; until stop=true; Baris program ini berfungsi agar aplikasi tetap membacakan teks sampai prosedur stop dimulai.

\section{g. Analisa Source Code MBROLA Tools}

Analisa source code dibawah ini adalah analisa source code untuk Microsoft Speech API, analisanya adalah sebagai berikut :

a. IndoTTS_Say(PChar(MSource.Text)); baris program ini berfungsi memanggil prosedur untuk membacakan teks berbahasa Indonesia.

b. INDOTTS_SpeakOff; baris program ini berfungsi menghentikan proses pembacaan teks berbahasa Indonesia.

\section{h. Analisa Hasil Kuisioner}

Analisa hasil uji coba juga dilakukan dengan cara pengisian kuisioner oleh responden. Responden mengisikan kuisioner setelah melihat uji coba program terlebih dahulu. Tujuan dari kuisioner dilakukan yaitu untuk mengetahui tingkat kepuasan dari responden yang menggunakan aplikasi ini dalam uji coba yang dilakukan.

Adapun pertanyaan yang diajukan kepada responden tentang aplikasi adalah sebagai berikut:

1. Apakah aplikasi ini dapat membantu anda mengetahui informasi melalui kegiatan mendengar secara baik? (Ya/Tidak).

2. Apakah anda merasa puas dengan hasil pembacaan teks bahasa Inggris oleh sistem? (Sangat Puas, Cukup Puas, Kurang Puas dan Tidak Puas).

3. Apakah anda merasa puas dengan hasil pembacaan teks bahasa Indonesia oleh sistem? (Sangat Puas, Cukup Puas, Kurang Puas dan Tidak Puas).

4. Tingkat kepuasaan anda menggunakan sistem konversi teks ke suara bahasa Indonesia dan bahasa Inggris secara keseluruhan : (Sangat Puas, Cukup Puas, Kurang Puas dan Tidak Puas).

Jumlah responden adalah 30 orang. Hasil dari kuisioner yang telah dilakukan adalah sebagai berikut :

a. Pertanyaan pertama, sejumlah 26 responden atau $86 \%$ menyatakan aplikasi ini dapat membantu dalam mengetahui informasi melalui kegiatan mendengar. Sedangkan 4 responden lainnya atau $14 \%$ menyatakan aplikasi ini tidak dapat membantu dalam mengetahui informasi melalui kegiatan mendengar.

b. Pertanyaan kedua, sejumlah 10 responden atau 33\% menyatakan sangat puas, 18 responden atau $60 \%$ menyatakan cukup puas, 2 responden atau $7 \%$ menyatakan kurang puas dengan hasil pembacaan teks berbahasa Inggris oleh sistem. Tidak ada responden yang menyatakan tidak puas dengan hasil pembacaan teks berbahasa Inggris oleh sistem. Grafi dapat dilihat pada gambar 10 . 


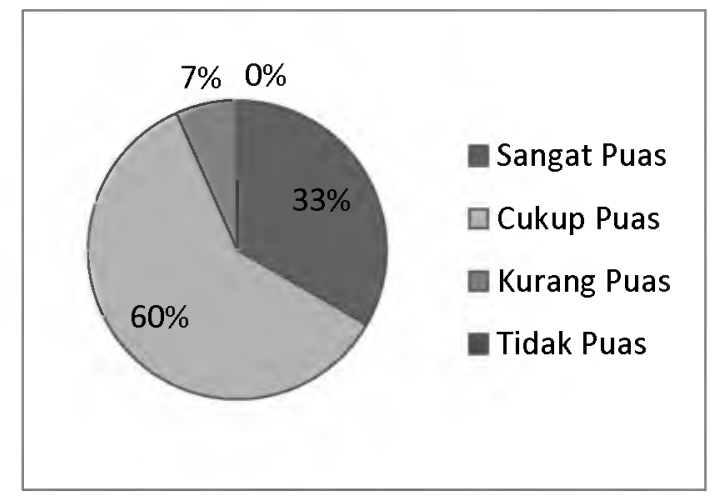

Gambar 10 Grafik Kuisioner Pertanyaan Kedua

c. Pertanyaan ketiga, sejumlah 5 responden atau $17 \%$ menyatakan sangat puas, 10 responden atau $22 \%$ menyatakan cukup puas, 15 responden atau $50 \%$ menyatakan kurang puas dengan hasil pembacaan teks berbahasa Indonesia oleh sistem. Tidak ada responden yang menyatakan tidak puas dengan hasil pembacaan teks berbahasa Indonesia oleh sistem. Grafik dapat dilihat pada gambar 11.

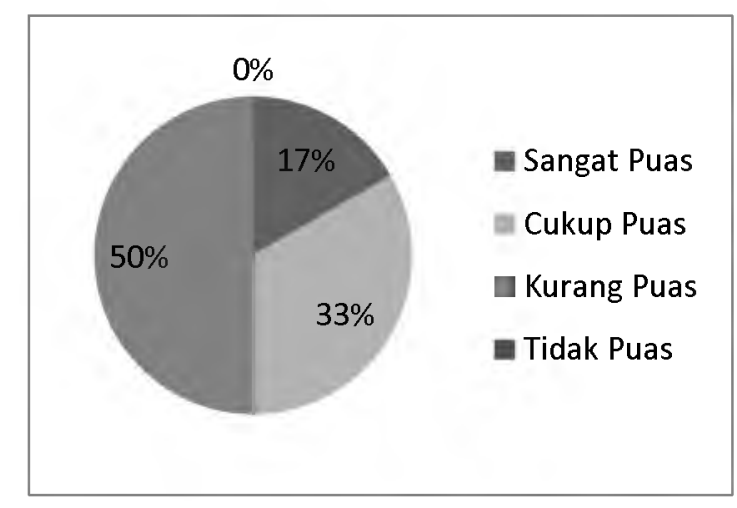

Gambar 11 Grafik Kuisioner Pertanyaan Ketiga

d. Pertanyaan keempat, sejumlah 7 responden atau 23\% menyatakan sangat puas, 23 responden atau $77 \%$ menyatakan cukup puas menggunakan sistem konversi teks ke suara bahasa Indonesia dan bahasa Inggris secara keseluruhan. Tidak ada responden yang menyatakan kurang puas dan tidak puas menggunakan sistem konversi teks ke suara untuk penerjemah bahasa Indonesia dan bahasa Inggris secara keseluruhan. Grafik dapat dilihat pada gambar 12 .

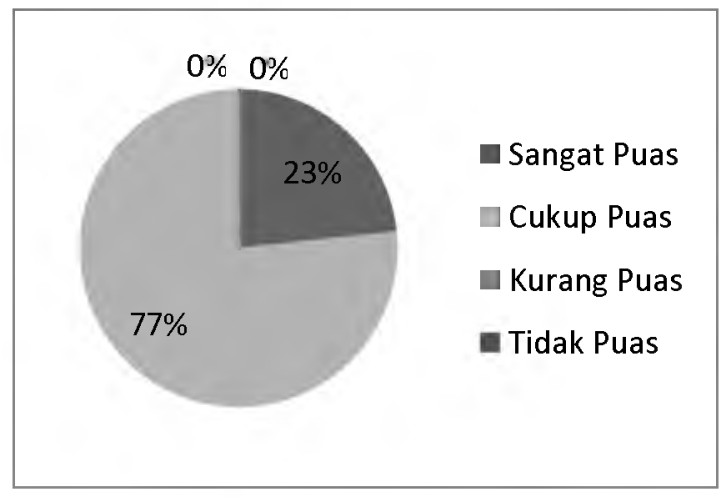

Gambar 12 Grafik Kuisioner Pertanyaan Keempat 
Sehingga melihat dari hasil kuisioner di atas maka dapat diambil kesimpulan dari tiap pertanyaan, sebagai berikut :

a. Aplikasi yang dibuat dapat membantu dalam mengetahui informasi melalui kegiatan mendengar.

b. Aplikasi yang dibuat efektif dan efisien untuk penerjemahan bahasa.

c. $60 \%$ responden menyatakan cukup puas dengan hasil pembacaan teks berbahasa Inggris oleh sistem.

d. $50 \%$ responden menyatakan kurang puas dengan hasil pembacaan teks berbahasa Indonesia oleh sistem.

e. $77 \%$ responden menyatakan cukup puas menggunakan sistem konversi teks ke suara bahasa Indonesia dan bahasa Inggris secara keseluruhan.

Kesimpulan kuisioner secara umum adalah:

Aplikasi yang dibuat dapat membantu dalam mengetahui informasi melalui kegiatan mendengar akan tetapi responden merasa cukup puas hanya pada hasil pembacaan teks berbahasa Inggris oleh sistem, sedangkan untuk hasil pembacaan teks berbahasa Indonesia oleh sistem responden masih merasa kurang puas. Secara keseluruhan responden menyatakan cukup puas menggunakan sistem konversi teks ke suara dalam bahasa Indonesia dan bahasa Inggris.

\section{KESIMPULAN DAN SARAN}

\section{a. Kesimpulan}

1. Algoritma Ari Borneo (AB) dapat digunakan untuk mengecek bahasa per paragraf dari tulisan yang terdiri dari banyak paragraf.

2. Sistem yang dibangun dapat digunakan untuk mendeteksi bahasa pada teks, yaitu bahasa Indonesia dan bahasa Inggris.

3. Sistem juga dapat membacakan teks menggunakan bahasa yang sudah terdeteksi oleh aplikasi.

4. Pengguna dapat menyerap informasi dari kegiatan mendengarkan pembacaan teks yang dilakukan oleh sistem.

b. Saran

1. Pengembangan terhadap sistem, sehingga tidak hanya bersifat aplikasi desktop saja tetapi juga dapat dibuat versi website dan versi mobile agar dapat diakses oleh banyak pengguna.

2. Aplikasi tidak hanya menerjemahkan dokumen berekstensi *.txt dan *.doc tetapi juga menerjemahkan dokumen yang berekstensi *.pdf.

\section{DAFTAR PUSTAKA}

Allen, Pamela. 2010. Membaca dan Membaca Lagi, Jurnal Compiler, Jakarta: Indonesia Tera.

Fadlisyah, Bustami, M. Ikhwanus. 2013. Pengolahan Suara, Jakarta: Graha Ilmu.

Madcoms. 2006. Pemograman Borland Delphi 7, Yogyakarta: Andi Publisher.

Madcoms. 2006. Pemograman Borland Delphi 7, Yogyakarta: Andi Publisher. 
Noertjahyana, Agustinus, Adipranata, Rudy. Implementasi Sistem Pengenalan Suara Menggunakan Sapi 5.1 Dan Delphi 5. Jurnal Informatika, Volume 4, No. 2, Tahun 2003, Pp. 96-102.

Ruthkoski, Traci L. 2013. Google Visualization API Essentials, Sakinaka: Packt Publishing.

Tritoasmoro, Iwan Iwut. 2006. Text-To-Speech Bahasa Indonesia Menggunakan Concatenation Synthesizer Berbasis Fonem. Seminar Nasional Sistem dan Informatika, 2006, SNSI06-028 .Bali.

Suherdi, Didi. 2013. Rekontruksi Pendidikan Bahasa, Jakarta : Dwitama Asrimedia.

Wahana Komputer. 2011. Panduan Aplikatif \& Solusi-Aplikasi Cerdas Menggunakan Delphi, Yogyakarta: Andi Offset. 